Szegedi Tudományegyetem, Fogorvostudományi Kar, Fogpótlástani Tanszék*

Szegedi Tudományegyetem, Fogorvostudományi Kar, Parodontológiai Tanszék**

Szegedi Tudományegyetem, Általános Orvostudományi Kar, Szülészeti és Nőgyógyászati Klinika***

Pécsi Tudományegyetem, Általános Orvostudományi Kar, Bioanalitikai Intézet****

Pécsi Tudományegyetem, Általános Orvostudományi Kar, Szülészeti és Nőgyógyászati Klinika*****

Pécsi Tudományegyetem, Általános Orvostudományi Kar, Fogorvostudományi Szak*****

\title{
Fiatal és középkorú férfiak fogazati és parodontológiai állapota Dél-Magyarországon
}

\author{
DR. PRÁGER NÁNDOR*, DR. GORZÓ ISTVÁN**, DR. PÁSZTOR NORBERT***, \\ DR. KÖNIG-PÉTER ANIKÓ****, DR. VÁRNAGY ÁKOS*****, DR. RADNAI MÁRTA******
}

\begin{abstract}
A felnőtt férfiak fogazati és parodontális állapotáról kevés adat található, holott több tanulmány mutatott összefüggést a szájban előforduló elváltozások és a szisztémás betegségek között. Vizsgálatot végeztünk férfiak körében a szájüregi egészségállapot felmérésére és annak kiderítésére, van-e összefüggés e között és a szocio-demográfiai tényezők, valamint a dohányzás között. A DMFT index 11,91, a DMFS index 24,28 volt, amelyben az átlagos életkor 34,9 év volt. A parodontológiai állapotot a következő adatokkal jellemeztük: plakk-index 0,71 volt, fogkő a fogak $29,74 \%$-án volt, a szondázási mélység átlaga $2,07 \mathrm{~mm}$, vérzést szondázásra a fogak $51,21 \%$-a mellett találtunk. A DMFT indexszel szignifikáns összefüggést mutatott az életkor, az iskolázottság, a foglalkozás, a plakk mennyisége, a szondázási mélység és a vérzés szondázásra gyakorisága. A parodontológiai állapotot az iskolai végzettség, a foglalkozás és a lakóhely befolyásolta. A dohányzás szignifikáns összefüggést mutatott a plakk-indexszel és a szondázási mélység átlagával. A megvizsgált férfiak szájüregi egészségi állapota alapján nagyobb hangsúlyt kellene fektetni a szájhigiénés motiválásra.
\end{abstract}

Kulcsszó: DMF, fiatal férfiak, középkorú férfiak, parodontológiai állapot, szondázási mélység, vérzés szondázásra

\section{Bevezetés}

Számtalan vizsgálat és tanulmány foglalkozik a gyermekek fogazati állapotával, de a felnőttek, főként a férfiak vonatkozásában sokkal kevesebb adat található a szakirodalomban. Bizonyítékok vannak azonban arra, hogy a rossz fogazati és parodontológiai állapot hatással lehet a beteg általános állapotára is; különböző szisztémás betegségek feltételezett oka lehet fogazati góc $[1,3,13,17]$. Az utóbbi években az is felmerült, hogy a gyermeket akaró párok körülbelül egyötödét érintő infertilitás is összefüggésben lehet a szájüregben fennálló kóros folyamatokkal, krónikus gyulladásokkal férfiak esetében [19]. Ennek alapján a krónikus periapikális gyulladás és a fogágybetegség felderítésének és kezelésének különös hangsúlyt kell kapnia a fogorvosi ellátásban.

Vizsgálatunk célja volt felmérni olyan fiatal felnőtt férfiak kariológiai és parodontológiai állapotát, akik infertilitás miatt kerestek fel andrológiai szakrendelést. További célkitűzés volt összefüggést keresni a szociodemográfiai tényezők és a dohányzás, valamit a fogazati és parodontológiai paraméterek között.

\section{Anyag és módszer}

Vizsgálatunkban 197 férfi vett részt, akik a Szegedi és a Pécsi Tudományegyetem andrológiai szakrendelésén jelentek meg, mert fertilitási problémákkal küzdöttek. Kizárólag egyébként egészséges férfiakat vontunk be a vizsgálatba. Azokat, akik valamilyen belgyógyászati betegségben szenvedtek és azokat, akiket a fogászati vizsgálat előtt antibiotikum profilaxisban kellett volna részesíteni, kihagytuk a felmérésböl. $A$ betegeket tájékoztattuk a fogorvosi vizsgálat lehetőségéről, akik ezután önkéntesen vettek részt a vizsgálatban, aláírva a beleegyező nyilatkozatokat. A vizsgálati protokollt a SZTE és a PTE etikai bizottságai elfogadták (97/2010 és 5126/2013).

A személyes adatok rögzítése után a résztvevők kérdőíven nyilatkoztak iskolai végzettségükröl, foglalkozásukról, esetleges káros szokásaikról, mint a dohányzás.

A fogazati státusz felmérését WHO [12] útmutatások szerint végeztük, a bölcsességfogakat kihagyva a vizsgálatból. A megvilágításhoz fogorvosi lámpát használtunk. Rögzítettük a karieszes, tömött, hiányzó, koronával ellátott fogakat és a még szájban látható radixo- 
kat. Ez utóbbiakat is tartalmazza a DMF-index. A parodontális elváltozások jellemzésére a következő mutatókat használtuk: Silness-Löe plakk-index, fogkőgyakoriság, szondázási mélység, vérzés szondázásra. A plakk-indexet a Ramfjord fogakon [16] határoztuk meg; négy fogfelszínen, 0-3 skálán értékeltük [18]. A látható fogkő jelenlétét foganként rögzítettük, tekintet nélkül annak mennyiségére. A szondázási mélységet a marginális ínyszél és a szulkusz legmélyebb pontja között milliméteres skálán mértük, minden fog körül hat heIyen (mezio-bukkálisan, bukkálisan, diszto-bukkálisan, diszto-lingválisan, lingválisan és mezio-lingválisan). Ehhez Michigan parodontális szondát használtunk (HuFriedy, USA), melynek $0,5 \mathrm{~mm}$ átmérőjü a vége. A vérzést szondázásra pozitívnak tekintettük, ha a szondázás után 15 másodpercen belül jelentkezett a fog bármelyik felszíne mellett [11].

A statisztikai elemezéshez a vizsgált személyeket ötéves korcsoportokra osztottuk. Iskolai végzettség alapján külön csoportba kerültek a csak általános iskolát végzettek, a szakmunkás képzésben résztvevők, az érettségizettek és a felsőfokú (főiskola, egyetem) végzettséggel rendelkezők. A foglalkozásokat három kategóriába soroltuk: fizikai munkás, szellemi dolgozó és egyéb, az előzőekhez nem sorolható foglalkozásúak. Külön csoportot alkottak a munkanélküliek. Megkülönböztettük a városban és falun élőket.

\section{Statisztikai módszerek}

Az átlagok közötti eltérések kimutatására t-próbákat és egyszempontos variancia analízist alkalmaztunk normális eloszlás esetében, egyébként pedig a Mann-Whitney és a Kruskal-Wallis próbákat. A minták normális eloszlását Kolgomorov-Szmirnov próbával ellenőriztük. Az adatok közt fennálló kapcsolatrendszert előzetesen Spearman-féle korrelációk számításával mértük fel.

\section{Eredmények}

A vizsgált személyek átlagos életkora 34,9 év volt, a legfiatalabb 25, a legidősebb 52 éves volt. Összesen 203 férfit vizsgáltunk meg, de az 50 év felettieket kihagytuk az elemzésből, így 197 fő adatait dolgoztuk fel. Általános iskolát végzett a páciensek 4,1\%-a, szakmunkástanuló iskolát $32,6 \%$, érettségizett 33,2\% és felsőfokú végzettsége volt a férfiak 30,1\%-ának. Munkanélküli volt a férfiak 3,1\%-a, fizikai munkásként dolgozott $42,5 \%$, szellemi foglalkozású volt $28,5 \%$, és az egyéb kategóriába soroltuk a vizsgáltak 25,9\%-át. Majdnem háromszor annyian laktak városban (71\%), mint falun (29\%). Káros szokások közül a dohányzás fordult elő értékelhető gyakorisággal, eszerint a férfiak 66,8\%-a nem, 33,2\%-a pedig dohányzott.

Az I. táblázat mutatja a kariológiai vizsgálat eredményeit. A DMFT- és DMFS-index alakulását életkor, isko- lai végzettség, foglalkozás és lakóhely szerint. A DMFTindex 11,91, a DMFS-index 24,28 volt a vizsgált csoportban. Az indexek nagyobbak voltak idősebb életkorban, a munkanélkülieknél, és kisebbek a felsőfokú végzettséggel rendelkezők és szellemi foglalkozást úzők körében, de szignifikáns különbség a csoportokon belül csak az életkor szerint volt $(P=0,000)$. A kariesz státusz tekintetében nem volt szignifikáns különbség a falun vagy városban élők, dohányosok és nem dohányzók között. A csoportokon belüli különbségeket mutatják a $P$ értékek; szignifikáns különbségek esetében jelöltük, mely csoportok értékei tértek el egymástól.

A kariesz-index összetevői szerinti bontásban a következők: a szuvas fogak átlaga 1,89, a tömött fogaké 5,61, a hiányzóké 3,0, a koronával ellátott fogak átlagos száma 0,87 , a radixoké 0,54 volt.

A parodontológiai státuszt jellemző adatokat, mint plakk-index, fogkő-előfordulás gyakorisága, szondázási mélység, valamint vérzés szondázásra, és ezen adatok megoszlását életkor, iskolai végzettség, lakóhely és dohányzás szerint az II-V. táblázatokban mutatjuk be. Az egész vizsgálati csoportra vonatkozóan a plakk-index értéke 0,71, fogkő a fogak 29,74\%-a mellett fordult elő, az átlagos szondázási mélység $2,07 \mathrm{~mm}$, vérzés szondázásra a fogak 51,21\%-a mellett jött létre. A vizsgált személyek $66,5 \%$-nak fogai mellett lehetett $\geq 4 \mathrm{~mm}$ szondázási mélységet mérni.

A statisztikai elemzés eredménye alapján a fogazat kariológiai állapotát szignifikánsan befolyásolta az életkor ( $P=0,000$ - DMFT és DMFS), a lakóhely $(P=0,049$ - DMFS) és a foglalkozás $(P=0,039$ és $P=0,006)$. A parodontológiai állapot fontos jellemzői közül a szondázási mélység szignifikáns összefüggést mutatott az iskolai végzettséggel $(P=0,001)$, a foglalkozással $(P=$ $0,005)$, a dohányzással $(P=0,006)$, a plakk átlaggal ( $P=0,000)$, a fogkő-előfordulás gyakoriságával $(P=$ $0,000)$ és a vérzés szondázásra gyakoriságával $(P=$ $0,000)$. $A \geq 4 \mathrm{~mm}$ mély tasakok előfordulási gyakorisága különbözött ugyan a csoportokban, például kisebb volt a nem dohányzók esetében, de szignifikáns különbség nem volt kimutatható. A másik fontos jellemző a vérzés szondázásra (BOP), amit leginkább az iskolázottság $(P=0,000)$, a lakóhely $(P=0,038)$, a foglalkozás $(P=0,000)$, a plakk ( $P=0,000)$ és a szondázási mélység $(P=0,000)$ befolyásolt. $A$ dohányzás ezen kívül szignifikáns összefüggést mutatott a szondázási mélység átlagával is $(P=0,003)$.

\section{Megbeszélés}

A vizsgált populációban a fogak és a fogágy állapotát (plakk-index, fogkőgyakoriság, szondázási mélység, vérzés szondázásra paramétereket tekintve) befolyásolták a szocio-demográfiai tényezők. A fogazat és a fogágy állapota egyértelműen a legidősebb korcsoportban volt a legrosszabb. A magasabb iskolai végzettséggel rendelkezők és szellemi foglalkozásúak átlagos DMF-indexe 
DMFT- és DMFS-indexek életkor, iskolai végzettség, foglalkozás, lakóhely és dohányzás szerint

\begin{tabular}{|c|c|c|c|c|c|c|c|}
\hline & $\mathbf{N}$ & $\begin{array}{c}\text { DMFT } \\
\text { Átlag } \pm \text { SD }\end{array}$ & $P$ érték & Stat & $\begin{array}{c}\text { DMFS } \\
\text { Átlag } \pm \text { SD }\end{array}$ & $P$ érték & Stat \\
\hline Korcsoportok & & & 0,000 & & & 0,000 & \\
\hline $25-29$ & 34 & $9,85 \pm 5,62$ & & 1 vs. $3,4,5$ & $17,41 \pm 11,43$ & & 1 vs. $3,4,5$ \\
\hline $30-34$ & 68 & $10,40 \pm 5,13$ & & 2 vs. 3 & $19,51 \pm 12,46$ & & 2 vs. 3 \\
\hline 35-39 & 55 & $13,65 \pm 5,49$ & & 2 vs. 4,5 & $29,25 \pm 14,75$ & & 2 vs. 4,5 \\
\hline $40-44$ & 29 & $13,62 \pm 4,51$ & & & $31,28 \pm 12,62$ & & \\
\hline $45-50$ & 11 & $14,36 \pm 5,92$ & & & $31,73 \pm 15,38$ & & \\
\hline Iskolai végzettség & & & 0,241 & & & 0,094 & \\
\hline Általános iskola & 8 & $11,25 \pm 5,04$ & & & $22,25 \pm 14,35$ & & \\
\hline Szakmunkásképző & 64 & $11,94 \pm 5,84$ & & & $26,09 \pm 15,56$ & & \\
\hline Középiskola & 65 & $12,97 \pm 5,12$ & & & $26,37 \pm 13,38$ & & \\
\hline Felsőfokú iskola & 59 & $10,98 \pm 5,47$ & & & $20,69 \pm 13,03$ & & \\
\hline Foglalkozás & & & 0,089 & & & 0,037 & \\
\hline Munkanélküli & 6 & $14,00 \pm 7,35$ & & 2 vs. 4 & $26,83 \pm 22,55$ & & 2 vs. 4 \\
\hline Fizikai dolgozó & 82 & $12,28 \pm 5,21$ & & 3 vs. 4 & $26,27 \pm 13,40$ & & 3 vs. 4 \\
\hline Egyéb & 50 & $12,84 \pm 5,02$ & & & $26,20 \pm 13,92$ & & \\
\hline Szellemi foglalk. & 55 & $10,48 \pm 5,90$ & & & $19,75 \pm 13,91$ & & \\
\hline Lakhely & & & 0,082 & & & 0,049 & \\
\hline Város & 140 & $11,47 \pm 5,52$ & & & $23,01 \pm 13,78$ & & \\
\hline Falu & 57 & $12,98 \pm 5,42$ & & & $27,42 \pm 14,78$ & & \\
\hline Dohányzás & & & 0,463 & & & 0,380 & \\
\hline Nem & 127 & $12,03 \pm 5,29$ & & & $24,50 \pm 13,87$ & & \\
\hline Igen, napi 5 szál & 28 & $11,45 \pm 5,40$ & & & $21,90 \pm 12,57$ & & \\
\hline Igen, napi 10 szál & 17 & $13,22 \pm 6,77$ & & & $27,83 \pm 17,00$ & & \\
\hline Igen, napi 20 szál & 18 & $11,74 \pm 5,75$ & & & $25,84 \pm 16,59$ & & \\
\hline Összes & 197 & $11,91 \pm 5,52$ & & & $24,28 \pm 14,25$ & & \\
\hline
\end{tabular}

Stat A szignifikancia szintje $<0,05$

\section{II. táblázat}

Plakk-index átlagok életkor, iskolai végzettség, foglalkozás, lakóhely és dohányzás szerint

\begin{tabular}{|l|r|c|l|c|}
\hline & N & $\begin{array}{c}\text { Plakk index } \\
\text { Átlag } \pm \text { SD }\end{array}$ & P érték & $\begin{array}{c}\text { Csoportok közötti } \\
\text { különbség }\end{array}$ \\
\hline Korcsoportok & & & 0,403 & \\
\hline $25-29$ & 34 & $0,80 \pm 0,53$ & & \\
\hline $30-34$ & 68 & $0,72 \pm 0,57$ & & \\
\hline $35-39$ & 55 & $0,62 \pm 0,51$ & & \\
\hline $40-44$ & 29 & $0,66 \pm 0,54$ & & \\
\hline $45-50$ & 11 & $0,91 \pm 0,84$ & & \\
\hline Iskolai végzettség & & & 0,000 & \\
\hline Általános iskola & 8 & $0,94 \pm 0,33$ & & 1 vs. 4 \\
\hline Szakmunkásképző & 64 & $0,95 \pm 0,77$ & & 2 vs. 3 \\
\hline Középiskola & 65 & $0,59 \pm 0,38$ & & 2 vs. 4 \\
\hline Felsőfokú iskola & 59 & $0,54 \pm 0,37$ & & \\
\hline Foglalkozás & & & 0,000 & \\
\hline Munkanélküli & 6 & $1,19 \pm 0,99$ & & 1 vs. 3 \\
\hline Fizikai dolgozó & 82 & $0,87 \pm 0,62$ & & 1 vs. 4 \\
\hline Egyéb & 50 & $0,64 \pm 0,50$ & & \\
\hline Szellemi foglalk. & 55 & $0,48 \pm 0,35$ & & 2 vs. 3 \\
\hline
\end{tabular}




\begin{tabular}{|l|r|l|l|l|}
\hline Lakhely & & & 0,040 & \\
\hline Város & 140 & $0,66 \pm 0,54$ & & \\
\hline Falu & 57 & $0,84 \pm 0,59$ & & \\
\hline Dohányzás & & & 0,019 & \\
\hline Nem & 127 & $0,63 \pm 0,51$ & & \\
\hline Igen, napi 5 szál & 28 & $0,70 \pm 0,58$ & & \\
\hline Igen, napi 10 szál & 17 & $0,87 \pm 0,49$ & & 1 vs. 4 \\
\hline Igen, napi 20 szál & 18 & $1,07 \pm 0,80$ & & 2 vs. 4 \\
\hline Összes & $\mathbf{1 9 7}$ & $\mathbf{0 , 7 1 \pm 0 , 5 6}$ & & \\
\hline
\end{tabular}

III. táblázat

Fogkö-előfordulás gyakorisága életkor, iskolai végzettség, foglalkozás, lakóhely és dohányzás szerint

\begin{tabular}{|c|c|c|c|c|}
\hline & $\mathbf{N}$ & $\begin{array}{c}\text { Fogkőgyakoriság } \\
\text { Átlag } \pm \text { SD (\%) }\end{array}$ & $P$ érték & \begin{tabular}{|c|}
$\begin{array}{c}\text { Csoportok közötti } \\
\text { különbség }\end{array}$ \\
\end{tabular} \\
\hline Korcsoportok & & & 0,729 & \\
\hline $25-29$ & 34 & $29,99 \pm 27,03$ & & \\
\hline 30-34 & 68 & $30,42 \pm 23,90$ & & \\
\hline 35-39 & 55 & $26,39 \pm 21,31$ & & \\
\hline $40-44$ & 29 & $31,77 \pm 26,40$ & & \\
\hline $45-50$ & 11 & $36,17 \pm 30,03$ & & \\
\hline Iskolai végzettség & & & 0,001 & \\
\hline Általános iskola & 8 & $58,75 \pm 29,07$ & & 1 vs. 2 \\
\hline Szakmunkásképző & 64 & $33,92 \pm 28,94$ & & 1 vs. 3 \\
\hline Középiskola & 65 & $26,95 \pm 19,74$ & & 1 vs. 4 \\
\hline Felsőfokú iskola & 59 & $24,56 \pm 19,86$ & & 2 vs. 4 \\
\hline Foglalkozás & & & 0,030 & \\
\hline Munkanélküli & 6 & $32,67 \pm 31,39$ & & \\
\hline Fizikai dolgozó & 82 & $34,40 \pm 27,75$ & & 2 vs. 4 \\
\hline Egyéb & 50 & $30,65 \pm 23,27$ & & \\
\hline Szellemi foglalk. & 55 & $21,93 \pm 17,05$ & & \\
\hline Lakhely & & & 0,133 & \\
\hline Város & 140 & $28,04 \pm 22,56$ & & \\
\hline Falu & 57 & $33,82 \pm 27,62$ & & \\
\hline Dohányzás & & & 0,084 & \\
\hline $\mathrm{Nem}$ & 127 & $26,92 \pm 21,97$ & & \\
\hline Igen, napi 5 szál & 28 & $32,31 \pm 26,03$ & & \\
\hline Igen, napi 10 szál & 17 & $43,72 \pm 31,39$ & & \\
\hline Igen, napi 20 szál & 18 & $32,63 \pm 28,32$ & & \\
\hline Összes & 197 & $29,74 \pm 24,40$ & & \\
\hline
\end{tabular}

Szondázási mélység átlaga és a $\geq 4 \mathrm{~mm}$ mély tasakok elöfordulási gyakorisága életkor, iskolai végzettség, foglalkozás, lakóhely és dohányzás szerint

\begin{tabular}{|l|r|c|c|c|c|}
\hline & $\mathbf{N}$ & $\begin{array}{c}\text { Szondázási } \\
\text { mélység } \\
\text { Átlag } \pm \text { SD }(\mathrm{mm})\end{array}$ & $\begin{array}{c}\text { P érték } \\
\text { Csoportok közötti } \\
\text { különbség }\end{array}$ & $\begin{array}{c}\geq \mathbf{4} \text { mm tasakok } \\
\text { gyakorisága }\end{array}$ & $\begin{array}{c}\text { P érték } \\
\text { Csoportok közötti } \\
\text { különbség }\end{array}$ \\
\hline Korcsoportok & & & 0,887 & & 0,651 \\
\hline $25-29$ & 34 & $2,08 \pm 0,59$ & & $11,23 \pm 16,00$ & \\
\hline $30-34$ & 68 & $2,08 \pm 0,52$ & & $10,16 \pm 15,66$ & \\
\hline $35-39$ & 55 & $2,01 \pm 0,57$ & & $8,96 \pm 18,03$ & \\
\hline $40-44$ & 29 & $2,09 \pm 0,52$ & & $9,13 \pm 15,33$ & \\
\hline $45-50$ & 11 & $2,23 \pm 0,48$ & & $14,09 \pm 20,41$ & \\
\hline
\end{tabular}




\begin{tabular}{|l|r|c|c|c|c|}
\hline Iskolai végzettség & & & 0,009 & & 0,113 \\
\hline Általános iskola & 8 & $2,50 \pm 0,28$ & 1 vs. 3 & $17,25 \pm 14,66$ & \\
\hline Szakmunkásképző & 64 & $2,20 \pm 0,61$ & 1 vs. 4 & $12,29 \pm 19,29$ & \\
\hline Középiskola & 65 & $1,98 \pm 0,44$ & 2 vs. 3 & $7,66 \pm 13,14$ & \\
\hline Felsőfokú iskola & 59 & $2,00 \pm 0,56$ & 2 vs. 4 & $9,54 \pm 16,75$ & \\
\hline Foglalkozás & & & 0,068 & & 0,275 \\
\hline Munkanélküli & 6 & $2,47 \pm 0,28$ & & $17,16 \pm 14,16$ & \\
\hline Fizikai dolgozó & 82 & $2,15 \pm 0,59$ & & $11,92 \pm 19,57$ & \\
\hline Egyéb & 50 & $2,05 \pm 0,56$ & & $9,27 \pm 14,60$ & \\
\hline Szellemi foglalk. & 55 & $1,96 \pm 0,46$ & & $7,50 \pm 13,02$ & \\
\hline Lakhely & & & 0,161 & & 0,197 \\
\hline Város & 140 & $2,04 \pm 0,55$ & & $9,50 \pm 16,60$ & \\
\hline Falu & 57 & $2,16 \pm 0,57$ & & $11,49 \pm 17,55$ & \\
\hline Dohányzás & & & & & 0,183 \\
\hline Nem & 127 & $2,01 \pm 0,53$ & & $8,71 \pm 15,42$ & \\
\hline Igen, napi 5 szál & 28 & $2,20 \pm 0,65$ & & $13,20 \pm 21,02$ & \\
\hline Igen, napi 10 szál & 17 & $2,18 \pm 0,52$ & & $12,61 \pm 15,46$ & \\
\hline Igen, napi 20 szál & 18 & $2,26 \pm 0,46$ & & $11,73 \pm 16,98$ & \\
\hline Összes & $\mathbf{1 9 7}$ & $\mathbf{2 , 0 7} \pm \mathbf{0 , 5 4}$ & & $\mathbf{1 0 , 0 8 \pm 1 6 , 5 2}$ & \\
\hline
\end{tabular}

Vérzés szondázáskor (BOP)

életkor, iskolai végzettség, foglalkozás, lakóhely és dohányzás szerint

\begin{tabular}{|l|r|c|c|c|}
\hline & N & $\begin{array}{c}\text { BOP } \\
\text { Átlag } \pm \text { SD (\%) }\end{array}$ & P érték & $\begin{array}{c}\text { Csoportok közötti } \\
\text { különbség }\end{array}$ \\
\hline Korcsoportok & & & 0,946 & \\
\hline $25-29$ & 34 & $54,62 \pm 35,00$ & & \\
\hline $30-34$ & 68 & $52,02 \pm 33,78$ & & \\
\hline $35-39$ & 55 & $49,06 \pm 31,82$ & & \\
\hline $40-44$ & 29 & $50,61 \pm 31,95$ & & \\
\hline $45-50$ & 11 & $48,08 \pm 32,48$ & & \\
\hline Iskolai végzettség & & & 0,001 & \\
\hline Általános iskola & 8 & $80,38 \pm 14,67$ & & 1 vs. 3 \\
\hline Szakmunkásképző & 64 & $60,25 \pm 30,96$ & & 1 vs. 4 \\
\hline Középiskola & 65 & $45,54 \pm 33,12$ & & 2 vs. 3 \\
\hline Felsőfokú iskola & 59 & $43,44 \pm 32,58$ & & 2 vs. 4 \\
\hline Foglalkozás & & & 0,002 & \\
\hline Munkanélküli & 6 & $78,17 \pm 26,98$ & & 1 vs. 4 \\
\hline Fizikai dolgozó & 82 & $56,49 \pm 33,28$ & & 2 vs. 4 \\
\hline Egyéb & 50 & $52,92 \pm 31,85$ & & \\
\hline Szellemi foglalkozású & 55 & $38,66 \pm 30,31$ & & 3 vs. 4 \\
\hline Lakhely & & & 0,039 & \\
\hline Város & 140 & $48,15 \pm 33,16$ & & \\
\hline Falu & 57 & $58,75 \pm 31,28$ & & \\
\hline Dohányzás & & & 0,278 & \\
\hline Nem & 127 & $48,14 \pm 33,09$ & & \\
\hline Igen, napi 5 szál & 28 & $50,97 \pm 32,19$ & & \\
\hline Igen, napi 10 szál & 17 & $58,06 \pm 28,30$ & & \\
\hline Igen, napi 20 szál & 18 & $64,74 \pm 33,15$ & & \\
\hline Összes & $\mathbf{1 9 7}$ & $\mathbf{5 1 , 2 1 \pm 3 2 , 8 5}$ & & \\
\hline & & & & \\
\hline
\end{tabular}


és parodontális állapota volt a legjobb. A dohányzás a plakk-indexszel és a szondázási mélység átlagával mutatott szignifikáns összefüggést. Vizsgáltuk a fogmozgathatóságot és ínyrecessziót, viszont olyan kevés esetben fordult elö, hogy statisztikai elemzés nem készült.

Kevés, a fiatal és középkorú férfiak fogazati állapotára koncentráló közlemény található a szakirodalomban. A hazai teljes populációra vonatkozó felmérés 20032004-ben történt [10]. A szerzők más korcsoportokat alkalmaztak, de az akkori DMFT-átlagok (12,28 a 2034 éveseknél, 14,73 a 35-44 éveseknél) valamivel magasabbak voltak, mint a jelen populációban $(9,85$ a $25-$ 29 , és 10,40 a 30-34 éveseknél). A különbség oka valószínűleg az, hogy a jelen vizsgálatban a férfiak egyharmada felsőfokú végzettségú volt és szellemi foglalkozásúként dolgoztak [2]. Ausztráliában katonának jelentkezők fogazati állapotát mérték fel 2002-2003ban [7]. A jelentkezők életkora 17-51 év között volt, összesen 973 jelöltet vontak be a vizsgálatba, akiknek $14 \%$-a volt nő. A hazai eredményeknél lényegesen alacsonyabb DMFT értékeket találtak: 26-30 éveseknél 5,48, a 31-35 éveseknél 7,01, a 36-51 éveseknél pedig 10,77 volt a DMFT érték. A jobban iskolázottak és magasabb jövedelműek itt is jobb fogazati státuszt mutattak, de a legfontosabb pozitív hatása a fogak állapotára a fluoridos ivóvíz fogyasztásának volt. Megismételve a felmérést, 2008-ban is hasonló eredményeket találtak [8]. Egy másik vizsgálatban középkorú felnőttek fogazatát mérték fel Sanghajban, Kína gazdasági központjában, 2005-ben. Az életkor 35-44 év között volt, a férfiak DMFT értéke 4,4 volt, jóval alacsonyabb az általunk ismertetett értéknél. A legkevésbé és a legjobban iskolázottak, valamint a nagyobb jövedelműek fogazata volt jobb, de nem találtak szignifikáns különbséget az egyes csoportok között [23].

A jelen vizsgálat eredményei alátámasztják azt a mindennapi gyakorlatban is tapasztalt tényt, hogy a magasabb iskolai végzettség, a nagyobb jövedelem és a szellemi foglalkozás általában jobb fogazati állapotot eredményez, bár a szakirodalomban sokféleképp definiálják az iskolázottság fokát, a foglalkozásokat és a jövedelmi kategóriákat vagy a társadalmi helyzetet [4].

A parodontológiai státusz összehasonlítása meglehetősen nehéz, mivel a közleményekben különféle indexek, életkori csoportosítások találhatók, és a szociális helyzet, iskolázottság sincs egyformán kategorizálva. Grúziában egy nagyobb felmérés alapján a fogágy állapota férfiak körében - hasonlóan saját vizsgálatunk adataihoz - nem tekinthető optimálisnak. Egészséges parodonciumot csak 33,1\%-ban találtak, igaz a vizsgálatba bevontak életkora 20-tól 74 évig terjedt. Nemek szerinti bontásban a szerzők nem tüntették fel a parodontológiai jellemzőket az életkori csoportok szerint. A vérzés szondázásra is elég nagy gyakorisággal fordult elő 38,4\% 20-24 éves csoportban, 46,9\% a 35-44 évesek csoportjában, nők és férfiak adatai együttesen voltak megadva. A magasabb iskolázottsággal rendelkezők és nagyobb jövedelműek jobb parodontális státuszt mutattak, de a különbség nem volt szignifikáns az öszszehasonlításokban [22].

Egy másik közleményben korai parodontitisz két fázisát különböztették meg, az egyes fokozatban $\leq 1,5 \mathrm{~mm}$, a kettes fokozatban $\geq 1,5 \mathrm{~mm}$ volt a tapadásveszteség. A $20-40$ éves férfiak $46 \%$-a került az egyes, $53 \%$-a a kettes csoportba. Eszerint a korai parodontitisz körülbelül minden második férfi esetében fennállt [21].

További hazai adatokkal való összehasonlításban Hermann és mtsai vizsgálatával vethetők össze az eredmények [6]. A 304 helységre kiterjedő, 4153 felnőttet magába foglaló vizsgálatban a Community Periodontal Indexet használták a parodontológiai állapot értékelésére (CPI). A férfiak $43 \%$-ának, míg a nők $28 \%$-ának voltak magas CPI adatai. A 20-34 korcsoportban csak 22,2\%, a 35-44 éves korcsoportban csak 10,6\% egészséges parodonciumú egyént találtak (férfiak és nők adatai együtt). Hasonlóan saját felmérésünkhöz, a fiatal és a középkorú férfiak parodontális állapota messze elmaradt az elvárttól ebben a vizsgálatban is.

Tekintettel arra, hogy korábbi, terhes nők körében végzett felmérésünkben a fent ismertetett csoportosításokat és paramétereket alkalmaztuk, a férfiak parodontológiai jellemzőit annak az eredményeivel lehet legkönnyebben összehasonlítani. Eszerint a férfiak parodontológiai állapota minden felosztásban rosszabb volt, mint a terhes nőké (plakk-index 0,67 vs. 0,71, fogkőgyakoriság $21,07 \%$ vs. 29,74), átlagos szondázási mélység $1,67 \mathrm{~mm}$ vs. $2,07 \mathrm{~mm}$, BOP $37,80 \%$ vs. $51,21 \%$ [15]. Bár a körülbelül tíz évvel ezelőtti felmérésben fiatalabb korcsoportok is voltak, de a terhesség alatt a hormonális változások miatt az ínyvérzés rendszerint gyakoribb, gingivitisz gyakran jön létre [14, 20].

Számos felmérésben bizonyították, hogy a dohányzás negatív hatással van a parodoncium állapotára [5, 9], ez azonban ebben a vizsgálati csoportban nem volt minden összehasonlításban kimutatható. A dohányzók és nem dohányzók között szignifikánsan különbözött a plakkindex $(P=0,019)$, de a többi tényező tekintetében nem volt statisztikailag kimutatható különbség, de az erős dohányosok (napi 20 szál cigaretta) esetében az átlagos szondázási mélység nagyobb volt és vérzés szondázásra gyakrabban jelentkezett. Ezek az eredmények egybehangzók az irodalomban talált adatokkal.

A vizsgálatban részt vevő fiatal és középkorú férfiak kariológiai és parodontális állapota alapján szükséges a felnőttek motiválása és instruálása is a szájhigiénia javítására és a fogorvosi ellenőrzésen való rendszeres megjelenésre.

\section{Szerzői munkamegosztás}

PN: hipotézis kidolgozása, vizsgálat lefolytatása, adatok elemzése, kézirat megszövegezése

Gl: hipotézis kidolgozása, kézirat korrekciója

$P N$ : vizsgálat szervezése

KPA: statisztikai elemzések 


\section{VA: vizsgálat szervezése}

RM: hipotézis kidolgozása, vizsgálat lefolytatása, adatok elemzése, kézirat korrekciója

A jelen tudományos közleményt a szerző(k) a Pécsi Tudományegyetem alapítása 650. évfordulója emlékének szenteli(k).

\section{Irodalom}

1. Azarpazhooh A, Leake JL: Systematic review of the association between respiratory diseases and oral health. J Periodontol. 2006; 77: 1465-1482.

2. Bernabé E, Suominen Al, Nordblad A, Vehralahti mm, Hausen H, KnuUTTILA M, et al.: Education level and oral health in Finnish adults: evidence from different lifecourse models. J Clin Periodontol. 2011; 38: 25-32.

3. Chambrone L, Guglielmetti MR, Pannutı CM, Chambrone LA: Evidence grade associating periodontitis to preterm birth andor low birth weight, I. A systematic review of prospective cohort studies. J Clin Periodontol.2011; 38: 795-808.

4. Costa SM, Martins CC, Bonfim Mde L, Zina LG, Paiva SM, Pordeus IA, et al.: A systematic review of socioeconomic indicators and dental caries in adults. Int J Environ Res Public Health. 2012; 9: 3540-3574. doi: 10.3390/ijerph9103540.

5. GELSKEY SC: Cigarette smoking and periodontitis: methodology to assess the strength of evidence in support of a causal association. Community Dent Oral Epidemiol. 1999; 27: 16-24.

6. Hermann P, Gera I, Borbély J, Fejérdy P, Madléna M: Periodontal health of an adult population in Hungary: findings of a national survey. J Clin Periodontol. 2009; 36: 449-457. doi: 10.1111/j.1600051X.2009.01395.X.

7. Hopcraft M, Morgan MV: Dental caries experience in Australian Army recruits 2002-2003. Aust Dent J. 2005; 50:16-20.

8. Hopcraft MS, Yapp KE, Mahoney G, Morgan MV: Dental caries experience in young Australian Army recruits 2008. Aust Dent J. 2009; 54: 316-322. doi: 10.1111/j.1834-7819.2009.01156.x.

9. Knight ET, Liu J, Seymour GJ, Faggion CM JR, Cullinan MP: Risk factors that may odify the innate and adaptive immune responses in periodontal diseases. Periodontol 2000. 2016; 71: 22-51. doi: 10.1111/prd.12110.
10. Madléna M, Hermann $P$, Jáhn M, Fejérdy P: Caries prevalence and tooth loss in Hungarian adult population: results of a national survey. BMC Public Health. 2008; 8: 364. doi: 10.1186/14712458-8-364.

11. Mühlemann HR, Son S: Gingival sulcus bleeding-a leading symptom in initial gingivitis. Helv Odontol Acta. 1971; 15: 107-113.

12. Oral Health Surveys Basic Methods, 3rd edition, WHO, Geneva 1987; 19-21.

13. Оtomo-Corgel J, Pucher JJ, Rethman MP, Reynolds MA: State of the science: chronic periodontitis and systemic health. $J$ Evid Based Dent Pract. 2012; 12: 20-28.

14. Raber-Durlacher JE, van Steenbergen TJ, Van der Velden U, de GraAFF J, ABRAHAM-INPIJN L: Experimental gingivitis during pregnancy and post-partum: clinical, endocrinological, and microbiological aspects. Journal of Clinical Periodontology. 1994; 21 : 549-558.

15. Radnal M, Gorzó I, Nagy E, Urbán E, Eller J, Novák T, Pál A: Terhes nők kariológiai és parodontológiai állapotának felmérése. II. A parodontális állapot. Fogorvosi Szemle. 2005; 98: 101-106.

16. RAMFJORD SP: Indices for prevalence and incidence of periodontal disease. J Periodontol. 1959; 30: 51-59.

17. Saremi A, Nelson RG, Tulloch-Reid M, Hanson RL, Sievers ML, TAYLOR GW, et al.: Periodontal disease and mortality in type 2 diabetes. Diabetes Care. 2005; 28, 27-32.

18. SILNESS J, LÖE H: Periodontal disease in pregnancy II. Correlation between oral hygiene and periodontal condition. Acta Odontol Scand. 1964; 22: 121-135.

19. Szkodziak P, Wozniak S, Czuczwar P, Wozniakowska E, Milart P, Mroczkowskı A, et al.: Infertility in the light of new scientific reports - focus on male factor. Ann Agric Environ Med. 2016; 23 : 227-230. doi: 10.5604/12321966.1203881.

20. Sooriyamoorthy M, Gower DB: Hormonal influences on gingival tissue: relationship to periodontal disease. Journal of Clinical Periodontology. 1989; 16: 201-208.

21. Tanner AC, Kent R Jr, Van Dyke T, Sonis ST, Murray LA: Clinical and other risk indicators for early periodontitis in adults. J Periodontol. 2005; 76: 573-581.

22. Tsitaishvili L, Kalandadze M, Margvelashvili V: Periodontal Diseases among the Adult Population of Georgia and the Impact of Socio-behavioral Factors on Their Prevalence. Iran J Public Health. 2015; 44: 194-202.

23. Wei Xu, Hai-Xia Lu, Cun-Rong LI, XIAO-LI Zeng: Dental caries status and risk indicators of dental caries among middle-aged adults in Shanghai, China. Journal of Dental Sciences. 2014; 9: 151-157.

\section{Práger N, Gorzó I, Pásztor N, Königné Péter A, Várnagy Á, Radnai M}

\section{Caries and periodontal status of young and middle-aged men in South-Hungary}

Background: There are only few studies available focusing on the oral health status of young and middle aged men; however chronic pathologic processes in the oral cavity and systemic diseases may have a cause relation connection. The aim of the study was therefore to examine and evaluate the caries and periodontal status of a group of young and middleaged men, and to find out if there was a connection between oral health, socio-demographic factors and smoking habits.

Material and methods: 197 systemically healthy men who had infertility problem were examined. Caries and periodontal status were examined and recorded. The data were statistically analyzed and compared according to age, educational level, profession, place of residence and smoking habits.

Results: Mean age of the men was 34,9 years. Mean DMFT index was 11,91, DMFS index 24,28 in the study group. Periodontal characteristics were as follows: plaque index 0,71 , frequency of calculus $29,74 \%$, mean probing depth $2,07 \mathrm{~mm}$, bleeding on probing occurred at $51,21 \%$ of the teeth. Significant connection was found between DMFT index and age, educational level, profession, plaque amount, probing depth and frequency of bleeding on probing. Periodontal status was influence by education level, profession and place of residence. Smoking had a significant connection with the plaque index and probing depth.

Conclusion: The oral health status of the young men was poor in this region of Hungary. Their motivation for oral health has to be improved and emphasized.

Key words: caries, DMF index, oral health, periodontal status, young men 